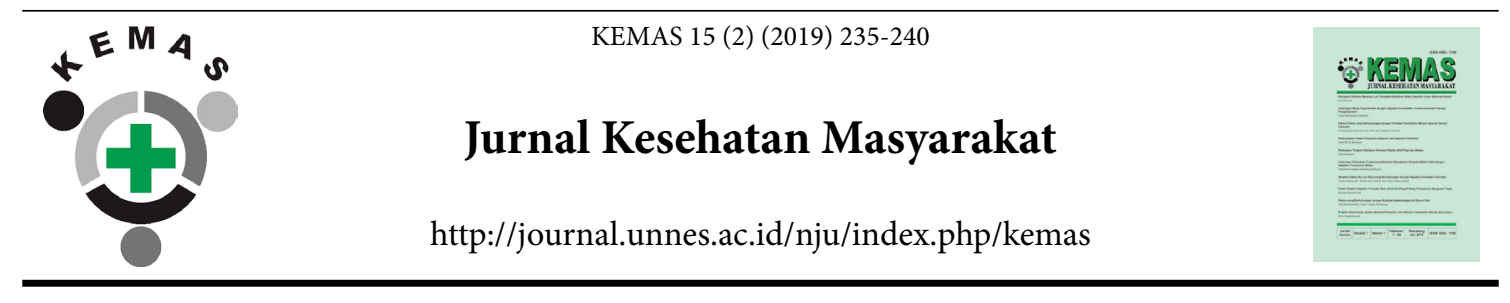

\title{
Knowledge, Behavior, and Role of Health Cadres in The Early Detection of New Tuberculosis Case in Wonogiri
}

\author{
Nita Yunianti Ratnasari ${ }^{\bowtie}$, Marni, Putri Halimu Husna \\ Nursing Academy of Giri Satria Husada Wonogiri
}

\begin{tabular}{l} 
Article Info \\
\hline Article History: \\
Submitted August 2019 \\
Accepted September 2019 \\
Published November 2019 \\
\hline Keywords: \\
Knowledge; Behavior, \\
Role; Cadres; Tuberculosis \\
\hline DOI \\
https://doi.org/10.15294/ \\
kemas.v15i2.20647
\end{tabular}

\begin{abstract}
Tuberculosis (TB) is an infectious disease that remain a serious health problem. Seventy five percent of TB cases in developing countries are found in people of productive age. Delay in case finding and handling will lead to disability and death and hamper TB control program. The objective of this study was to evaluate how far the role of health cadres in detecting new case of TB in Tirtomoyo, Wonogiri. The study design was a cross-sectional and data was collected from February to April 2019. The population of the study was all health cadres in Tirtomoyo numbering 465 cadres from 9 villages. Sample of the study was the cadres in Tirtomoyo who met inclusion criteria set by the researchers with total number of 202 cadres. The sampling technique was purposive sampling, and the inclusion criteria included: active person, in a healthy state, not currently receiving inpatient care in hospital, and agree to participate in the study. Subjects completed the questionnaire consisting of sociodemographic data, knowledge, behavior, and the role of cadre. The data was analyzed using SPSS version 22 . The behavior of the health cadres was found to significantly correlate to the role of cadres in early detection of new TB cases with $\mathrm{p}$ value of 0.039 (OR $0.121-0.946$ ). The health cadres play an essential role, and active screening for TB detection was more effective than passive screening. Early diagnosis would affect the success of the TB treatment program.
\end{abstract}

\section{Introduction}

Tuberculosis (TB) is a communicable disease which remain a serious health problem worldwide until present. In 2012, the incidence of TB was 8.6 million and the rates of death reached 1.3 million (Bulage, Sekandi, Kigenyi, \& Mupere, 2014). Delay in case detection and handling was related to disability and death, as well as impeded the TB control program. An effective strategy was needed to improve the new case detection of TB (Wingfield \& Verguet, 2017).

In developing countries, $75 \%$ of $\mathrm{TB}$ cases affected productive population - at the age of 15 to 50 year-old (Atika, 2009). In 2015, the rates of TB detection in Indonesia was more than $70 \%$ (Simamora, 2017). On the other hand, in Wonogiri Regency in 2015 there were 302 Acid Fast Bacteria positive/AFB (+) patients and the Case Detection Rate (CDR) was $28.21 \%$. Compared to data in 2014, AFB (+) patients were 375 , or the CDR was $35.70 \%$. Therefore, based on patients and case detection rate, there was a decline from the previous year. Several factors causing the low in CDR included the Passive Case Finding (PCF) of the TB control program to encompass cases and the case screening was less strict (too sensitive) (Musyafa, Rahayujati, \& Indriyanti, 2017b). Therefore, the role of health cadres in detecting tuberculosis needed a reinforcement. One of indicators of TB prevention program in Indonesia supporting it was Case Notification Rate (CNR), through a case finding to screen 
the suspected TB case (Musyafa, Rahayujati, \& Indriyanti, 2017a).

In $\mathrm{TB}$ eradication effort, World Health Organization (WHO) stated the need of participation from several stakeholders besides the government (Harahap, Amelia, Wahyuni, \& S, 2018). Those support included effort on behavior change and community reinforcement (A.Korobitsyn et al., 2013). A study from Tajikistan in 2013 presented interesting results, among others was that the knowledge of TB in community generally increased, but TB related stigma persist, obstructing effective detection of TB cases (A.Korobitsyn et al., 2013).

Tuberculosis is a contagious disease caused by Mycobacterium tuberculosis bacteria. The main pulmonary symptom is productive cough for 2 weeks or more. Cough could be followed other symptoms such as blood-stained sputum, bloody cough, dyspnea, weakness, low appetite, weight loss, malaise, night sweat without physical activity, low fever more than a month. In a patient with HIV positive, often the main symptom was not a cough, therefore, there was no definition of 2 weeks or more for cough (RI, 2018).

This study aimed to evaluate the role of the health cadres in the early detection of TB cases. This determination was crucial because of the abundant negative stigmatization in community related to $\mathrm{TB}$ infection. If active detection of TB case succeeded, it is expected to improve $\mathrm{TB}$ prevention and eradication programs.

Method

The was a cross-sectional study, whose population was all of health cadres in Tirtomoyo Wonogiri numbering of 465 cadres from 9 villages. Sample was the cadres in Tirtomoyo which met the eligibility in the inclusion criteria. Sampling was carried out using purposive sampling. Inclusion criteria are: cadres with active status in Puskesmas (Community Health Center), healthy, not hospitalized, agree to participate in the study. There were 202 cadres eligible to participate and they completed instrument consisting of sociodemographic, knowledge, behavior, and role of the cadre, that was analyzed in SPSS program version 22. The instrument consisted of a list of questions designed by the author. Sociodemographic questionnaire consisted of age, gender, level of education, occupation, income, support from officers and family members, as well as the duration of being a cadre. The secondary data consisted of role, knowledge, and behavior of the cadre. The analyses used univariate test to view the characteristic of the respondents, role, behavior and knowledge of the cadres. We conducted bivariate analysis to assess correlation between independent variables and respondents characteristics. The logistic regression was the multivariate analysis used to view the candidate variables related to TB early detection.

\section{Result and Discussion}

Sociodemographic data of the participants was presented in Table 1 .

Table 1. Sociodemographic variables $(n=202)$.

\begin{tabular}{ll}
\hline Variables & $\mathrm{n}(\%)$ \\
\hline Less than 30 & $178(88.1)$ \\
More than 30 & $24(11.9)$ \\
Gender & \\
Male & $1(0.5)$ \\
Female & $201(99.5)$ \\
Education level & \\
Lower & $113(55.9)$ \\
Higher & $89(44.1)$ \\
Occupation & \\
Non-worker & $121(59.9)$ \\
Worker & $81(40.1)$ \\
Income (monthly) & \\
Less than 1 million & $202(100)$ \\
More than 5 million & 0 \\
Support from officers and family & \\
Less & $8(4.0)$ \\
Good & $194(96.0)$ \\
Role of cadre & \\
Less & $123(60.9)$ \\
Good & $79(39.1)$ \\
Knowledge of cadre & \\
Poor & $3(1.5)$ \\
Good & $199(98.5)$ \\
Behavior & \\
Poor & $28(13.9)$ \\
Good & $174(86.1)$ \\
\hline Source primary data &
\end{tabular}

Source: primary data 
Table 2. Correlation between variable of sociodemographic, level of knowledge, behavior, and the role of cadre in early detection of new TB case $(n=202)$.

\begin{tabular}{lllll}
\hline Variable & Category & Role & p value \\
\cline { 3 - 4 } & & Poor & Good & \\
\hline Age & Less than 30 & 109 & 69 & 0.785 \\
Education level & More than 30 & 14 & 10 & \\
\multirow{2}{*}{ Occupation } & Lower & 72 & 41 & 0.354 \\
\multirow{2}{*}{ Support from family and } & Higher & 51 & 38 & \\
officer & Non-worker & 66 & 55 & $0.023^{*}$ \\
Knowledge of cadre & Worker & 57 & 24 & \\
& Poor support & 7 & 1 & 0.152 \\
Behavior & Supported & 116 & 78 & \\
& Poor & 3 & 120 & 0.282 \\
& Good & 0 & 79 & \\
& Poor & 23 & 100 & $0.009^{*}$ \\
& Good & 5 & 74 &
\end{tabular}

Information: ${ }^{\star}$ ) Statistically significant

Table 3. Logistic regression of factors affecting the role of cadre in early detection of new TB case $(\mathrm{n}=202)$.

\begin{tabular}{ll}
\hline Variable & Factors Affecting The Role of Cadre in TB Case Finding \\
\hline Occupation & $0.068(0.958, \quad 3.241)$ \\
Behavior & $0.039^{\star}(0.121, \quad 0.946)$
\end{tabular}

Information: $\left.{ }^{\star}\right)$ Statistically significant

Among 202 participants, there were $178(88.1 \%)$ respondents less than 30 yearsold, the other $24(11.9 \%)$ respondents was more than 30 years-old. A total of $194(96 \%)$ respondents stated that their family members or officers provide full support, while only 8 (4\%) respondents stated having less support. A total of 199 (98.5\%) participants have good knowledge, while the other 3 (1.5\%) participants have less knowledge. On the domain of the role of cadre, $174(86.1 \%)$ respondents have good behavior and 28 (13.9\%) respondent showed the opposite.

Table 2 showed a significant correlation between occupation and the role of cadre with $\mathrm{p}=0.023(\mathrm{p}<0.05)$ and also between behavior and the role of cadre with $\mathrm{p}=0.009(\mathrm{p}<0.05)$. Logistic regression analysis tested candidate variable of the role of cadre in early detection of new TB case in the community (Table 3). The result revealed that behavior of the cadre significantly correlate to the role of the cadre in early detection of new TB case with $p$ value of 0.039 (OR $0.121-0.946$ ).
This study aimed to evaluate how far the level of knowledge and behavior of the cadres impact the role of health cadres in improving the rates of early detection of new TB case in community. Compliance on treatment was one of the defining factor of the success in new TB case handling. However, compliance rates of the patients was often actually low (Ratnasari \& Nurtanti, 2018). The establishment of Pengawas Minum Obat/PMO (Medication Caregiver) was a primary strategy to encourage compliance of TB patients (Suharyo \& Mubarokah, 2018). A study conducted in Saudi Arabia showed several factors impacting the quality of life of TB patients, such as age, education level, occupation, and marital status (Al-qahtani et al., 2014). Patients with chronic comorbid disease, i.e Diabetes Mellitus, had an increased risk of pulmonary TB infection (Siddiqui, 2009). This condition could be treated through early detection and antibiotic administration, although negative stigma on TB patients might affect the long- 
term decline of psychological well-being of the patients (Ahmad, Nazir, \& Ahmad, 2018). Therefore, a continuous improvement of therapy supervision was critical (Ibrahim, Ibrahim, Aly, \& Messery, 2017). Moreover, other intervention such as counselling, health education, as well as adequate support was mandatory in patients with MDR-TB. It is expected to improve the management and to limit the drop out case (Adiwinata, Rasidi, Marpaung, Timur, \& Timur, 2018). An effective early diagnosis and pharmacotherapy would be key to reduce failure of TB treatment (Bhatt, Chopra, \& Vashisht, 2019). Report from WHO in 2017 stated that 6.3 million population have potential to contract positive TB infection, justifying the importance of early disease detection to determine the global health care program (Golichenari et al., 2018).

In this study, the occupation of the cadres significantly correlate to the role of the cadres in early detection of TB case. Presently, community-based active detection of TB case in a emerged in several countries (Saunders et al., 2019). The limitation on resources, commitment of the healthcare providers, and health information were the main factors causing the low rates of early detection of TB case (Dabaro, 2017). The screening method and the approach of the test needed improvement to support the new TB case finding (Sander et al., 2019). Active detection of new TB case became a recommendation as an essential strategy in controlling $\mathrm{TB}$, particularly in low-middle income countries with a high prevalence of TB infection (Thomas Lung, Guy B Marks, Nguyen Viet Nhung, Nguyen Thu Anh, Nghiem Le Phuong Hoa, Le Thi Ngoc Anh \& Warwick John Britton, Jessica Bestrashniy, Stephen Jan, 2019). Active detection approach in a proper manner could improve the finding of new TB case in a short term (Fa, Le, Dacombe, Mkopi, $\&$ Sinclair, 2017). WHO targeted an eradication of TB disease in 2035. For this reason, a new strategy of early detection was needed to effectively detect TB case. An active detection showed a more effective case finding compared to passive action for detection, indicating it could be incorporated in early detection strategy as well as in early treatment strategy (Ho, Fox, \& DC, 2016). It was consistent with the study stating that a delay of diagnosis and low treatment compliance could increase the incidence of drug resistance TB (Sormin et al., 2018).

This study showed a significant correlation between behavior of the cadres and the role of cadres in early detection of new TB case, with $\mathrm{p}$ value of 0.039 ( $\mathrm{p}<0,05)$, OR (0.121 - 0.946), which means that the better the behavior of the cadres, the better and larger the role of the cadres in case detection. Besides, friendly healthcare providers could improve the motivation and the compliance of patients (Widjanarko, Gompelman, Dijkers, Maartje, \& Werf, 2009). Good communication between patients and healthcare providers and politeness of the officers were expected to be able to improve the patients' compliance on the treatment (Gebreweld et al., 2018). Other factors affecting the officers in tracking the case included knowledge, behavior, and practical action. Reduced motivation and poor commitment of the officers were personal factors that might interfere the performance (Tlale, Frasso, Kgosiesele, Selemogo, \& Quirk Mothei5, Dereje Habte1, 2016). There were a significant and positive correlation between knowledge, behavior, motivations of the officers and the probable-TB identification (Simamora, 2016). A study in Zambia toward the TB officers revealed that one of 18 officers died due to TB, while 18 of 1,757 staffs and volunteers were diagnosed with TB within 1 year (Verver et al., 2018).

\section{Conclusion}

The occupation and behavior of the cadres were the defined factors affecting the role of the cadres in early detection of TB case in the community. This result supported the importance of health cadres in the community, because an active action of detection of TB case was more effective compared to passive action of detection. Early diagnosis would strongly affect the success of the treatment program of the TB patients.

This result suggested a step to increase the knowledge of the cadres through a mentoring program and health education to the cadres, especially of that is related to skills needed in early detection of new TB case.

\section{Acknowledgement}


The author would like to thank the Director of Nursing Academy of Giri Satria Husada Wonogiri, Head of Health Officer of Wonogiri Regency, Head of Puskesmas Tirtomoyo as well as the cadres group who agreed to participate as a respondents in this study.

\section{Reference}

A.Korobitsyn, O.Bobokhojaev, T., Mohr, Ismoilova, J., M., ... Trusov1., 2013. TB case detection in Tajikistan - analysis of existing obstacles. Central Asian Journal of Global Health, 2(2). https://doi.org/10.5195/cajgh.2013.48

Adiwinata, R., Rasidi, J., Marpaung, M., Timur, K., \& Timur, K., 2018. Profil Klinis dan Evaluasi Pengobatan Pasien RifampicinResistant dan Multidrug-Resistant Tuberculosis di RSUD Dr. Kanujoso Djatiwibowo Balikpapan. J Respir Indo, 38(3), 135-142. Retrieved from http://jurnalrespirologi.org/index.php/jri/ article/view/2/5

Ahmad, S., Nazir, N., \& Ahmad, Z., 2018. ScienceDirect Original article A prospective study on quality of life in patients with pulmonary tuberculosis at a tertiary care hospital in Kashmir , Northern India. Indian Journal of Tuberculosis, 66(1), 118-122. https://doi.org/10.1016/j.ijtb.2018.07.002

Al-qahtani, M. F., Ali, A., Mahalli, E., Dossary, N. $\mathrm{Al}$, Muhaish, A. Al, Otaibi, S. Al, \& Baker, F. Al., 2014. Health-related quality of life of tuberculosis patients in the Eastern Province , Saudi Arabia. Journal of Taibah University Medical Sciences, 9(4), 311-317. https://doi. org/10.1016/j.jtumed.2014.04.005

Atika, D. N., 2009. Pattern Of Community Role Development As An Effort To Increase. Folia Medica Indonesiana, 45(2), 108-111.

Bhatt, R., Chopra, K., \& Vashisht, R., 2019. ScienceDirect Original article Impact of integrated psycho-socio-economic support on treatment outcome in drug resistant tuberculosis - A retrospective cohort study. Indian Journal of Tuberculosis, 66(1), 105-110. https://doi.org/10.1016/j.ijtb.2018.05.020

Bulage, L., Sekandi, J., Kigenyi, O., \& Mupere, E., 2014. The Quality of Tuberculosis Services in Health Care Centres in a Rural District in Uganda: The Providers' and Clients 'Perspective. Tuberculosis Research and Treatment, 2014. Retrieved from http:// dx.doi.org/10.1155/2014/685982

Dabaro, D., 2017. J Clin Tuberc Other Mycobact Dis Factors a ff ecting tuberculosis case detection in Kersa District, South West. J Clin Tuberc
Other Mycobact Dis, 9(January), 1-4. https:// doi.org/10.1016/j.jctube.2017.08.003

Fa, M., Le, C., Dacombe, R., Mkopi, A., \& Sinclair, D., 2017. Interventions to increase tuberculosis case detection at primary healthcare or community-level services ( Review ). Cochrane Database of Systematic Reviews Interventions, (11). https://doi. org/10.1002/14651858.CD011432.pub2. www.cochranelibrary.com

Gebreweld, F. H., Kifle, M. M., Gebremicheal, F. E., Simel, L. L., Gezae, M. M., Ghebreyesus, S. S., ... Wahd, N. G., 2018. Factors influencing adherence to tuberculosis treatment in Asmara, Eritrea: a qualitative study. Journal of Health, Population and Nutrition, 37(1), 1. https://doi.org/10.1186/s41043-017-0132-y

Golichenari, B., Velonia, K., Nezami, A., Farokhifard, A., Behravan, J., Tsatsakis, A. M., ... Nosrati, R., 2018. Label-free nano-biosensing on the road to tuberculosis detection. Biosensors and Bioelectronic. https://doi. org/10.1016/j.bios.2018.04.059

Harahap, J., Amelia, R., Wahyuni, A. S., \& S, A. L., 2018. Community empowerment program for increasing knowledge and awareness of tuberculosis patients, cadres and community in Medan city Community empowerment program for increasing knowledge and awareness of tuberculosis patients, cadres and community in Meda. IOP Conf. Series: Earth and Environmental Science, 125. https://doi. org/doi : 10.1088/1755-1315/125/1/012102

Ho, J., Fox, G. J., \& DC, B. J. M., 2016. Passive case finding for tuberculosis is not enough. International Journal of Mycobacteriology 5 (2016) 374 - 378, 374-378. https:// doi.org/http://dx.doi.org/10.1016/j. ijmyco.2016.09.023

Ibrahim, E., Ibrahim, A., Aly, M., \& Messery, A., 2017. Egyptian Journal of Chest Diseases and Tuberculosis Pattern of prevalence, risk factors and treatment outcomes among Egyptian patients with multidrug resistant tuberculosis. Egyptian Journal of Chest Diseases and Tuberculosis, 66(3), 405-411. https://doi.org/10.1016/j.ejcdt.2016.11.002

Musyafa, A., Rahayujati, T. B., \& Indriyanti, H., 2017a. Tuberculosis_ case finding in public health center of Blora, Indonesia. Berita Kedokteran Masyarakat (BKM Journal of Community Medicine and Public Health), 33(11). https:// doi.org/https://doi.org/10.22146/bkm.38189

Musyafa, A., Rahayujati, T. B., \& Indriyanti, H., 2017b. Tuberculosis: case finding in public health center of Blora, Indonesia. Berita 
Kedokteran Masyarakat (BKM Journal of Community Medicine and Public Health) Volume, 33(11).

Ratnasari, N. Y., \& Nurtanti, S., 2018. Analysis on Factors Related with Treatment Behavior of Pulmonary Tuberculosis Patient. Jurnal Kesehatan Masyarakat (Kemas), 14(1), 8189. https://doi.org/https://doi.org/10.15294/ kemas.v14i1.12518

RI, K., 2018. Infodatin (Pusat Data dan Informasi Kementerian Kesehatan RI). In Tuberkulosis (ISSN 2442-). Kementerian Kesehatan RI. Pusat Data dan Informasi.

Sander, M. S., Laah, S. N., Titahong, C. N., Lele, C., Kinge, T., Jong, B. C. De, ... Creswell, J., 2019. J Clin Tuberc Other Mycobact Dis Systematic screening for tuberculosis among hospital outpatients in Cameroon: The role of screening and testing algorithms to improve case detection. J Clin Tuberc Other Mycobact Dis, 15, 100095. https://doi.org/10.1016/j. jctube.2019.100095

Saunders, M. J., Tovar, M. A., Collier, D., Baldwin, M. R., Montoya, R., Valencia, T. R., ... Evans, C. A., 2019. Articles Active and passive casefinding in tuberculosis-affected households in Peru : a 10-year prospective cohort study. The Lancet Infectious Diseases, 3099(18), 1-10. https://doi.org/10.1016/S14733099(18)30753-9

Siddiqui, A. M., 2009. Clinical Manifestations and Outcome of Tuberculosis in Diabetic Patients Admitted to King Abdulaziz University Hospital in Jeddah, Saudi Arabia. Journal of Taibah University Medical Sciences, 4(2), 148-155. https://doi.org/10.1016/S16583612(09)70103-9

Simamora, R. H., 2016. The Correlation Between Knowledge, Attitude and Motivation of Cadre With The Tuberculosis Suspect Identification in The Padang Bulan Public Health Center 2016. Faculty Of Nursing Universitas Sumatera Utara.

Simamora, R. H., 2017. A Strengthening of Role of Health Cadres in BTA-Positive Tuberculosis ( TB ) Case Invention through Education with Module Development and Video Approaches in Medan Padang bulan Comunity Health Center, North Sumatera Indonesia. International Journal of Applied Engineering Research ISSN 0973-4562, 12(20), 10026-10035.

Sormin, D. E., Siagian, P., Sinaga, B. Y. M., Eyanoer, P. C., Adam, R. H., \& Medan, M., 2018. Neutrophyl Lymphocyte Ratio pada Pasien Tuberkulosis Paru dan Tuberkulosis Resisten
Obat Neutrophyl Lymphocyte Ratio in Tuberculosis Patients and Multi Drug Resistant Tuberculosis Patients. J Respir Indo, 38(3), 177-180. Retrieved from http:// jurnalrespirologi.org/index.php/jri/article/ view/8/3

Suharyo, \& Mubarokah, K., 2018. Development Model of Household Contacts as a Peer Support to Decrease The Prevalence of Pulmonary Tuberculosis. Jurnal Kesehatan Masyarakat (Kemas), 13(5), 404-410. https:// doi.org/https://doi.org/10.15294/ kemas. v13i3.10632

Thomas Lung, Guy B Marks, Nguyen Viet Nhung, Nguyen Thu Anh, Nghiem Le Phuong Hoa, Le Thi Ngoc Anh, N. B. H., \& Warwick John Britton, Jessica Bestrashniy, Stephen Jan, G. J. F., 2019. Household contact investigation for the detection of tuberculosis in Vietnam: economic evaluation of a cluster-randomised trial. Www.thelancet.com/lancetgh. Retrieved from www.thelancet.com/lancetgh Vol 7 March 2019

Tlale, L., Frasso, R., Kgosiesele, O., Selemogo, M., \& Quirk Mothei5, Dereje Habte1, A. S., 2016. Factors influencing health care workers' implementation of tuberculosis contact tracing in Kweneng, Botswana. Pan African Medical Journal, 8688, 1-9. https://doi. org/10.11604/pamj.2016.24.229.7004

Verver, S., Kapata, N., Simpungwe, M. K., Kaminsa, S., Mwale, M., Mukwangole, C., ... Meis, M., 2018. Feasibility of district wide screening of health care workers for tuberculosis in Zambia. BMC Public Health, 18(17), 1-9. https://doi.org/10.1186/s12889-017-4578-z

Widjanarko, B., Gompelman, Dijkers, M., Maartje, \& Werf, M. J. van der., 2009. Factors that influence treatment adherence of tuberculosis patients living in Java, Indonesia. Patient Preference and Adherence, 3, 231-238. Retrieved from https://www.ncbi.nlm.nih. gov/pmc/articles/PMC2778426/pdf/ppa-3231.pdf

Wingfield, T., \& Verguet, S., 2017. Comment Active case finding in tuberculosis-affected households: time to scale up. The Lancet Global Health, 7(3), e296-e298. https://doi. org/10.1016/S2214-109X(19)30015-4 